\title{
Empowering or Boring? Discipline and Authority in a Portuguese Sistema-Inspired Orchestra Rehearsal
}

\author{
Pedro S. Boia \\ CIPEM/INET-md, Porto Polytechnic, Portugal \\ Graça Boal-Palheiros \\ CIPEM/INET-md, Porto Polytechnic, Portugal
}

El Sistema orchestras may be "transformative" and produce positive changes in the lives of young participants, but there are also negative aspects to discipline and authority that may lead to exclusion. This article positions itself within the current debate on Sistema by treating symmetrically its potentially positive and negative sides. We analyse a rehearsal session during a summer camp of a Portuguese Sistema-inspired orchestra program, focusing on the production of order, the socio-musical interactions among participants, the conductor's leadership and authority, and the young players' postures and reactions. This is taken as a case study to discuss to what extent discipline and authority, as constituents of orchestral socialization, may be empowering to participants by developing their skills or, on the contrary, symbolically violent and boring. The rehearsal was video-recorded and watched, events were categorized, selected and analysed qualitatively. The article finishes with a critical reflection on the ambivalence and contradictions of discipline and its wider implications for education.

Keywords: El Sistema; orchestra rehearsal; discipline; skills; social inclusion

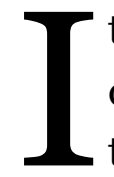

$\mathrm{t}$ has been argued and widely publicized that El Sistema orchestras produce positive changes in the lives of their young participants by fostering their social inclusion through the "transformative power of music" and "musical excellence" (Tunstall 2012; Verhagen, Panigada, and Morales 2016). This view frequently reflects the standpoint of practitioners and authors who are themselves deeply engaged with and strongly support El Sistema. This dominant discourse has been thus criticized for being too emotionally-driven, subjective, and idealistic. As a follow-up to the call for the need of a rational and analytical approach to El Sistema (Baker 2014), it has been shown, for instance, that there are negative aspects related to discipline, authority, and control which may lead to exclusion and other problems (Baker 2014; Baker 
2016; Bates 2016-see the Special Issue of ACT 15(1) devoted to El Sistema) (for a comprehensive literature review on El Sistema see Creech, GonzálezMoreno, Lorenzino, Waitman 2016).

This article ${ }^{1}$ situates itself within the current debate on El Sistema and similar socio-artistic intervention programs by exploring the nuanced shades between these two opposite perspectives of the program's proponents and detractors. Acknowledging the complexity of the issues under discussion, we present a case study of Orquestra Geração in Portugal to explore the contradictions and ambivalence implicated in the aim of fostering social inclusion through these projects. We treat symmetrically and give equal space to potentially positive and negative implications of moderately high levels of authority and discipline in orchestral rehearsals.

Orquestra Geração [OG] is the Portuguese incarnation or appropriation of the El Sistema program of youth orchestras. Similarly to its Venezuelan counterpart, it is primarily aimed at fostering the social inclusion, academic success at school, and social and personal development, through music, of children and adolescents considered more vulnerable or at risk. In the case of the nuclei considered in this article, participants live in the Lisbon metropolitan area, often in social housing neighbourhoods associated with poverty, ethnic diversity, school failure, and sometimes violence (see Mota and Lopes 2017).

Recent research suggests that participation in OG may foster the social inclusion and social mobility of young participants through the acquisition of dispositions and skills during the socialization process within the orchestra project (Lopes, Boia, Veloso, Caldas 2017). Dispositions are durable and transposable principles or organized schemes that, after being internalized by social agents through socialization, generate predispositions for acting, thinking and judging in certain ways rather than others (Bourdieu [1972] 1977, [1980] 1990; Lahire 2003, [2001] 2011).

Sociological portraits based on qualitative interviews with thirty-five OG participants (Lopes, Boia, Veloso, Caldas 2017) suggest that dispositions that facilitate group work and relational skills, sense of responsibility, concentration at school, discipline, attention and mutual respect, and time management and self-regulation skills, tend to be internalized at OG and are potentially transposable to other realms of life, such as school and eventually future jobs. ${ }^{2}$ Not only may those dispositions configure themselves as skills socially valued in academic and professional life but, as shown by the aforementioned authors, participation in OG also shapes participants' wishes and projects for

Boia, Pedro S., and Graça Boal-Palheiros. 2017. Empowering or Boring? Discipline and authority in a Portuguese Sistema-inspired orchestra rehearsal. Action, Criticism, and Theory for Music Education 16 (2): 144-72. doi:10.22176/act16.2.144 
their future, influencing their actions in the pursuit of those aims. These changes may thus empower the young participants by widening the range of possibilities for their future trajectories. However, some of the OG young participants also pointed out criticisms of $O G$ in the interviews, and two of them expressed resistance to the disciplining exerted by/within the orchestra.

This article addresses socio-musical practices and interactions between participants during an OG rehearsal, that are part of the work carried out collectively to achieve a common goal: effective rehearsals followed by good public performances. Particular attention will be given to the production of order and the organization of participants' practices and postures. A specific rehearsal session is a privileged opportunity to investigate and reflect on discipline, authority, cooperation, and resistance among conductor and players. Empirical analysis will be followed by a critical discussion on the role and contradictions of discipline and its wider implications for education.

\section{A summer camp rehearsal session as a case study}

Summer camps are special events in which OG nuclei from various locations gather in one venue to rehearse and play together under guest conductors, some of whom are from Venezuela's El Sistema. Children spend a few days away from home, daily schedules are fully devoted to section and tutti rehearsals, and there are several concert performances, often in prestigious concert halls. Summer camps are intended to be a response, even if temporary, to the quest for an "intensity" (in terms of work, number of participants and sonic outcome) similar to Venezuela's El Sistema (Costa et al. 2017, 151-2).3 Even though more intense, the orchestral work carried out at summer camps has features in common with the everyday orchestral routines and training that take place during the rest of the school year. On the other hand, of course, summer camp activities represent specific moments of OG's life and have their own particularities and contingencies.

This study investigates one orchestra rehearsal during the annual OG summer camp in July 2013 as part of several rehearsals that were filmed during this event. 4 The session is an especially interesting case study (Stake 2008) for approaching order, discipline, authority, cooperation and resistance. Simultaneously, it provides interesting moments for the analysis of orchestral socialization in real-time, helping us understand how music may be transformative.

Boia, Pedro S., and Graça Boal-Palheiros. 2017. Empowering or Boring? Discipline and authority in a Portuguese Sistema-inspired orchestra rehearsal. Action, Criticism, and Theory for Music Education 16 (2): 144-72. doi:10.22176/act16.2.144 
A video camera was positioned strategically in the rehearsal room in an unobtrusive place near one of the walls. It was adjusted to a wide angle that captured as much of the action as possible (Heath, Hindmarsh, and Luff 2010). At some moments, the camera was picked up and zoomed-in to focus on relevant details of the action. The recordings were subsequently viewed, in full, multiple times. Relevant excerpts were categorized and analysed qualitatively, although some of the events were also quantified whenever possible and relevant. The aim was to focus on what conductors, teachers and students say and do and how they interact, considering words, bodily gestures, and embodiment, as well as aspects of the musical performance.

\section{Discipline, authority and production of order}

'Orquestra B', formed by the gathering of several pre-existing OG Lisbon nuclei, was one of the ensembles that participated in the summer camp. The young players were approximately between 12 and 16 years old and the concert repertoire consisted of arrangements of Mussorgsky's 'Great Gate of Kiev' (from 'Pictures at an Exhibition') and 'Hopak', Tchaikovsky's 'Trepak' (from 'The Nutcraker'), the 'Ode to Joy' from Beethoven's 9th Symphony, and Isaac's 'Gipsy Overture'.5

The ensemble was working with a guest conductor from Venezuela's El Sistema and rehearsals were taking place daily in a school classroom. This was a hot summer afternoon and the night before they had just given a concert performance in a prestigious hall. This rehearsal had the duration of approximately three hours. The entire first half of the session, analysed in this article, lasted approximately one hour and fifteen minutes and was exclusively devoted to practicing "scale techniques." After a break in the middle of the session, the second half of the rehearsal would be devoted to preparing the concert repertoire for approximately an hour and fifteen minutes.

This case study focuses on the first half of the session. Our primarily aim is to approach discipline, the conductor's authority and the production of order in the rehearsal setting, and the players' postures and reactions. In doing so, the analysis will also shed light into some of the devices through which orchestral socialization in real-time takes place, helping us to understand how it may have consequences for the sets of dispositions and skills of the young participants (see Figure 1).

Boia, Pedro S., and Graça Boal-Palheiros. 2017. Empowering or Boring? Discipline and authority in a Portuguese Sistema-inspired orchestra rehearsal. Action, Criticism, and Theory for Music Education 16 (2): 144-72. doi:10.22176/act16.2.144 


\begin{tabular}{|c|c|c|c|}
\hline Categories & \multicolumn{2}{|l|}{ Subcategories } & \begin{tabular}{|l|} 
Events \\
\end{tabular} \\
\hline \multirow{5}{*}{$\begin{array}{l}\text { 1. Conductor's gestural } \\
\text { and verbal leadership }\end{array}$} & \multicolumn{2}{|l|}{ 1.1-pitch } & \multirow{5}{*}{ [numerous] } \\
\hline & \multirow{2}{*}{\multicolumn{2}{|c|}{\begin{tabular}{|l} 
1.2-rhythm \\
1.3-dynamics
\end{tabular}}} & \\
\hline & & & \\
\hline & \multicolumn{2}{|l|}{ 1.4-articulation } & \\
\hline & \multicolumn{2}{|c|}{ 1.5-playing in sequence/canon } & \\
\hline \multirow[t]{3}{*}{$\begin{array}{l}\text { 2. Disciplining bodies } \\
\text { and minds }\end{array}$} & \multirow[t]{2}{*}{$\begin{array}{l}\text { 2.1- increasing } \\
\text { tension }\end{array}$} & $\begin{array}{l}\text { 2.1.1- stimulating atten- } \\
\text { tion/motivating }\end{array}$ & $\begin{array}{l}\text { conductor clapping the } \\
\text { beat loudly and walking } \\
\text { around, encouraging } \\
\text { and telling participants } \\
\text { to play } \\
\text { [7 events] }\end{array}$ \\
\hline & & $\begin{array}{l}\text { 2.1.2- body posture/ } \\
\text { performance ethos }\end{array}$ & $\begin{array}{l}\text { conductor asks players } \\
\text { to "sit on the edge of the } \\
\text { chair" } \\
\text { [3 times] }\end{array}$ \\
\hline & \multicolumn{2}{|c|}{$\begin{array}{l}\text { 2.2- decreasing tension (resting and in- } \\
\text { creasing mental concentration) }\end{array}$} & $\begin{array}{l}\text { relaxation and imagery } \\
\text { exercise } \\
{[1 \text { event }]}\end{array}$ \\
\hline $\begin{array}{l}\text { 3. Conductor's mani- } \\
\text { festation of authority }\end{array}$ & \multicolumn{2}{|c|}{ 3.1- negative reinforcement } & $\begin{array}{l}\text { threatening to delay the } \\
\text { break if participants do } \\
\text { not focus and play the } \\
\text { scales accurately } \\
\text { [twice] }\end{array}$ \\
\hline $\begin{array}{l}\text { 4. Final verbal feed- } \\
\text { back }\end{array}$ & \multicolumn{2}{|c|}{$\begin{array}{l}\text { 4a.- stimulating self-assessment } \\
\text { 4b.- highlighting the importance of being } \\
\text { focused } \\
\text { 4c.- expressing trust but no condescend- } \\
\text { ence }\end{array}$} & [1 event] \\
\hline \multirow[t]{3}{*}{$\begin{array}{l}\text { 5. Young participants' } \\
\text { postures and reactions }\end{array}$} & \multicolumn{2}{|c|}{$\begin{array}{l}\text { 5.1- cooperation with conductor and } \\
\text { group }\end{array}$} & [most of the time] \\
\hline & \multicolumn{2}{|c|}{$\begin{array}{l}\text { 5.2- helping conductor maintaining order } \\
\text { and discipline }\end{array}$} & $\begin{array}{l}\text { "let us hear" ["shhh"?] } \\
\text { [2 events] }\end{array}$ \\
\hline & \multicolumn{2}{|c|}{ 5.3- disruptive behaviours } & $\begin{array}{l}\text { giggling, talking, react- } \\
\text { ing slowly } \\
\text { [sometimes] }\end{array}$ \\
\hline
\end{tabular}

Figure 1. Categorization of rehearsal events

Boia, Pedro S., and Graça Boal-Palheiros. 2017. Empowering or Boring? Discipline and authority in a Portuguese Sistema-inspired orchestra rehearsal. Action, Criticism, and Theory for Music Education 16 (2): 144-72. doi:10.22176/act16.2.144 


\section{Conductor's leadership and getting in tune together}

With body gestures afforded by music materials (Godøy 2010) and through verbal instructions, conductors lead their orchestras socially and aesthetically in an ongoing relational process between them and the musicians through which they "show them the sound" (Koivunen 2011) (see Figure 1 - category 1). The maestros' typical bodily gestures are largely a cultural convention of learned body technique (Mauss [1934] 1973) with its specific "economies" (Dineen 2011). Acquiring these gestural codes is part of the background necessary for becoming a conductor of Western 'classical' music. Despite this, there are variations and different maestros have particular features and idiosyncrasies that configure what people call 'musical personality' or 'style', which refers to the uses of the body and gestures-angular or round, narrower or broader, moving the whole body or just the arms; quieter or harsher 'temperament' in the relationship with musicians-more authoritarian or gentle; talking more or less (e. g. see the video-documentary The Art of Conducting: Great conductors of the past, Knussen 1994). These variations are not purely individual but depend also on socialization and background.

In this rehearsal session, the guest conductor moves his arms to indicate that participants should start playing and in which tempo, frequently clapping the beat while counting loud "one, two, three, and..." Sometimes he walks around prominently through the middle of the musicians. He gives verbal direction to participants, guiding them cognitively by either providing them with instructions and feedback on dynamics, articulation, rhythm and intonation, or by explaining or reminding them the structure of scales (e.g. place of the half-tones in each major and minor scale). To stimulate awareness and help players remind what they had (supposedly) learned previously, he asks questions about scales and modes (e.g. "F major, so where are the flats?"). He also gives instructions related to instrumental technique (e.g. "for more piano play with this part of the bow"). This assures not only correspondence to a certain aesthetic and respective socio-aesthetic values, but also disciplines everyone to use their bodies and instruments similarly in order to play the same music at the same time and in the same manner.

Practices in OG are grounded on the 'orchestra' and the 'conductor' as institutions, which means they are framed by historically and culturally organized modes of making, teaching, and learning music. In the historical development of the orchestra, discipline has been crucial. "Because orchestral

Boia, Pedro S., and Graça Boal-Palheiros. 2017. Empowering or Boring? Discipline and authority in a Portuguese Sistema-inspired orchestra rehearsal. Action, Criticism, and Theory for Music Education 16 (2): 144-72. doi:10.22176/act16.2.144 
music requires many instrumentalists to play the same thing at the same time, orchestras demand a high degree of musical discipline" (Spitzer and Zaslaw n.d.). The aesthetic aim of achieving similar intonation, attack, articulation, dynamics, phrasing, bowings and even fingerings explains the emergence and the institutionalization of the role of the conductor, particularly from the 19th century onwards (see Spitzer, Zaslaw, and Kennedy n.d.). The conductor became institutionalized during the 19th century, when orchestras became larger with more players, which made it more difficult to play in a coordinated way. Having developed from the earlier "time beaters," the conductor stands on the top of the orchestra's hierarchy. With his conventionalized conducting gestures, he plays a crucial role in helping the musicians "play the same thing at the same time." That homogenization helps the orchestra become more than a mere collection of separate individuals and turn it into a collective entity.

The "scale techniques" practiced in OG rehearsals consist in playing scales, frequently in the same keys of the concert programme musical pieces, with variations of rhythm, articulation (legato, staccato), and dynamics (forte, piano, crescendo, diminuendo) for instance (see subcategories 1.1-1.5). As the players rehearse the scales during this session, they progressively 'tune-in' to each other socially and musically (Schutz 1951) and begin to sound more in tune and more precisely together in time. The maestro plays a crucial role in this process by 'orchestrating' their collective cognitive and embodied musicmaking actions through the authority afforded by his status.

\section{Energizing and motivating the players: increasing tension}

The rehearsal routine is very intense during summer camps. It is hot and the young players, who had just given a concert the previous evening, appear to be tired. The conductor attempts to motivate and discipline their bodies and minds, postures and actions (Figure 1-category 2) through two distinctive strategies:

i) Increasing tension (sub-category 2.1)

ii) Decreasing tension (2.2).

He tries to increase the players' bodily-mental tension and stimulate their attention by counting and clapping the beat loudly ("one, two, three..."). He urges them to play with energy despite the high temperature: "come on!", "wake up," or "we must play." He occasionally shushes them. He walks around

Boia, Pedro S., and Graça Boal-Palheiros. 2017. Empowering or Boring? Discipline and authority in a Portuguese Sistema-inspired orchestra rehearsal. Action, Criticism, and Theory for Music Education 16 (2): 144-72. doi:10.22176/act16.2.144 
with an assertive presence and bold bodily gestures which seem energizing (2.1.1-seven events).

Some players often look either very tired or demotivated, laying back on their chairs and prostrated with their instruments (especially some wind players sitting in the back). "Oh, but what spirit [ironically]... almost sleeping," says the conductor, singing the scale in a dull way (imitating how it sounded when they played it) and pretending to fall asleep. He claps and snaps his fingers and walks around: "let's go! Wake up everyone." The maestro disciplines the players' body postures and performance ethos whenever he feels they lack energy, by telling them to sit "on the edge of the chair" (2.1.2-3 events). ${ }^{6}$ This is a way to make them more active and focused, bodily and cognitively, and induce a more committed attitude towards music making.

These devices are employed by the conductor to motivate, re-energize, and discipline the players' bodies, minds, and practices. They are also ways to cope with their tiredness, after the previous evening performance and intense work during the week. Later on, the conductor attempts to decrease the players' tension through a relaxation exercise, but first we will analyse a peak moment in the manifestation of his authority.

\section{A peak moment of authority: negative reinforcement}

An explicit manifestation of the conductor's status and power towards the players happened during a peak moment of authority, through the use of negative reinforcement (see Figure 1-3.1). After some players had been playing wrong notes in the scales, missing the flats or sharps, the conductor sits on his chair with his arms crossed. Looking slightly impatient, he reminds players that so far they only did eight out of the twenty-four scales of the tonal system. "That's very little"-there are "twelve" more to go.

He threatens to postpone the scheduled break: "so, if we want to have the break, we'll put a smile on our face and do C major and then a minor." While he speaks, he makes an ironic, forced smile, pushing the corner of his mouth upwards with his fingers. At this moment, the players giggle and a couple of them protest with an "aah..." [in descending pitch]. The maestro's facial expression turns more serious now, apparently expressing some impatience. Right after mimicking their "aah...," he has a deeper, more serious tone, raises his eyebrows and says a bit louder: "because if you don't do it ... we'll continue

Boia, Pedro S., and Graça Boal-Palheiros. 2017. Empowering or Boring? Discipline and authority in a Portuguese Sistema-inspired orchestra rehearsal. Action, Criticism, and Theory for Music Education 16 (2): 144-72. doi:10.22176/act16.2.144 
and then play A flat major and then $\mathrm{f}$ minor." "What do you think? Eh?" Some of the students still smile and giggle.

Now his mood turns more relaxed and, denoting complicity and empathy with the players as if he were their older brother he says "so, a little smile on your faces and let's play $\mathrm{C}$ major." He immediately stands up and, once again, starts clapping vigorously to motivate and re-energize them and increase their intensity.

The same threat will happen again a bit later. This time, students are silent, and the conductor talks more quietly, advising them without any irony: "We'll make the break after playing these scales ... well" (stressing this word). "If we play them well we'll have a break; if we don't do it well we will repeat it. So, for you it's better to play them well at once." "Let's go, C major"-he says vigorously. He then claps with energy saying "go, go, go...!" loudly while accelerating the speed of these words.

The conductor tried to condition the players' behaviour through negative reinforcement (Skinner [1953] 2014, 174-8). When he threatened to postpone a previously scheduled pleasant stimulus (the break), the time added to postpone the break was likely to be an aversive stimulus to many of the players, who had been showing signs of tiredness. The removal of this aversive stimulus (the extra time) will happen as soon as the participants do as he wishes. The strategy is intended to increase a desirable behaviour: concentrating and playing the scales well. The expected outcome is that players will do their best to 'get it right' as quickly as possible in order to avoid the negative stimulus or, as Skinner writes, "escape" from it.

Regarding this strategy as negative reinforcement or as a threat of punishment may be a matter of perspective: if we take instead what the conductor perceived as 'lack of concentration' as the reference behaviour, we may consider that this was an undesired behaviour that he wanted to decrease when he postponed the pleasant stimulus (the break). On the other hand, the break might be seen as a reward that must be deserved in order to be received.

The negative reinforcement was connected to intense repetition of the material played, and both aspects have been pointed out as important features of the original Venezuelan El Sistema's socio-musical pedagogical practices (Baker 2014). During the entire first half of this rehearsal, which lasted slightly over one hour and fifteen minutes, the orchestra played eight scales. Repetition together with authority were intentionally used as strategies for teaching and learning with the aim of increasing the players' skills. As a "labor-

Boia, Pedro S., and Graça Boal-Palheiros. 2017. Empowering or Boring? Discipline and authority in a Portuguese Sistema-inspired orchestra rehearsal. Action, Criticism, and Theory for Music Education 16 (2): 144-72. doi:10.22176/act16.2.144 
intensive organization" (Baker 2014, 133; see Tunstall 2012, 28-9), discipline and authority have been also referred to as strong aspects of El Sistema orchestras (see Baker 2014).

What was the point? The conductor's 'lecture' shortly before the break

Shortly before the end of the first half of the rehearsal, the conductor takes some time to talk to the players. In this important moment, he seems to be trying to make them see the point of all his previous insistence for focusing and playing the scales and his use of authority. Lengthier verbal feedback appears as yet another strategy for trying to make the players cooperate and improve their performance.

When he asks participants to be quiet and listen, some are unfocused, giggling and chatting a bit, but others are sitting quietly. One of the players helps him maintain orderly behavior: "stop talking!" she says assertively to a colleague (we also hear another "shh"). Progressively they all calm down. Finally, there is silence and the conductor begins to talk. There were three moments in his verbal feedback (sub-categories $4 \mathrm{a}, \mathrm{b}, \mathrm{c}-$ Figure 1):

1) First, he stimulates the young players' self-critical awareness and selfassessment by asking "do you think it was ok?" Completely focused, they reply assertively "no" (sub-category 4a). "Do you know what happened?" [silence] "Can anyone tell me why we did it well when we played it in sections and now that we played the whole scale it didn't work?" Some respond "lack of concentration." "Exactly!" he replies, stressing that was also why some things did not go well during the previous evening concert performance.

2) Then, he highlights the importance of staying focused to perform well (4b) and gives more examples from the previous evening's concert: "when students lose their focus, all the work we have done is worthless: the cellos run, [etc.]", "so, one must focus towards the great aim"-the concert. The concert performance itself is used in his discourse as a motivational factor for making them do their best in rehearsals.

3) Finally, the conductor expresses his trust in the participants, "well, I trust you and what you have learned," but he shows no complacence for mistakes (4c): "because of the tiredness in your faces or lack of

Boia, Pedro S., and Graça Boal-Palheiros. 2017. Empowering or Boring? Discipline and authority in a Portuguese Sistema-inspired orchestra rehearsal. Action, Criticism, and Theory for Music Education 16 (2): 144-72. doi:10.22176/act16.2.144 
concentration I will not give in, 'oh you poor guys'." Waving 'no' with his finger, he shows no concession through that embodied gesture.

It sounds as if the conductor is 'lecturing' the participants, but seemingly with their best interests in mind and empathy, to make them realize 'the whole point' of the tour de force of all the scale playing they did during the entire first half of the rehearsal, which lasted approximately one hour and fifteen minutes: practicing concentration, but also persistence and stamina. The internalization of such dispositions and skills, as pointed out earlier, may be useful for performing both musical and extra-musical activities and is thus potentially empowering.

In other words, the 'lecture' served to "do things with words" (Austin 1962), to produce a certain construction of reality through the use of language and performative "speech acts" (Searle 1969). Specifically, it seemed a means to convey the idea that the conductor acted in such way because he wants the best for the young players and cares about them. Simultaneously, it prevented them from interpreting the conductor's actions as an expression of his will to 'punish' them or to be mean (an alternative reality construction). The verbal feedback was one more ingredient of the maestro's motivational strategy that sought to legitimize or, at least, provide a rationale-a justification-for his approach.

Dealing with unresponsiveness by decreasing tension: relaxation exercise

Right after threatening to delay the break, the conductor attempted to immediately restart the playing through vigorous clapping and words (e.g. "go, go, go...!”). Both times, however, many of the players reacted very slowly or did not react at all, even though others picked up their instruments and were immediately prepared to play, waiting for the others. Many were unfocused, giggling or turning their heads to each other and chatting, looking either tired or bored. Objectively, their inaction slowed down the rehearsal pace and delayed their return to scale playing.

The maestro seemed to be struggling against inertia, despite all the clapping and verbal encouragement. Possibly feeling that the approach used so far (increasing tension) was not working anymore and the negative reinforcement did not produce the expected results, he reacted by radically inverting his strategy towards decreasing tension (Fig. 1-2.2). He presents what one might call a relaxation and imagery exercise. He tells the players to rest, lay down the

Boia, Pedro S., and Graça Boal-Palheiros. 2017. Empowering or Boring? Discipline and authority in a Portuguese Sistema-inspired orchestra rehearsal. Action, Criticism, and Theory for Music Education 16 (2): 144-72. doi:10.22176/act16.2.144 
instruments on their laps and lean back in their chairs for one minute. "Let's close our eyes," he says, quieting them down with "sh[ush] shh, shh..."-one student in the back is still giggling. A quiet mood is successfully set and the participants follow his instructions.

This exercise seemed a device employed by the maestro to deal with the slight increase of undisciplined and disruptive behaviour of participants. It regulated and disciplined their bodies and minds by decreasing tension and making them relax. It also allowed them to rest and increase their attention, refocus and 'recharge batteries' for the task they needed to accomplish, helping to improve their performance and have their break.

Another aim of the exercise was to stimulate the players' ability to anticipate and imagine the structure of the scale in their heads. With a softer voice, the conductor tells them the features of the scales of $\mathrm{C}$ major and the relative key of A minor, which they will play next (what is the key signature, in which degrees are the minor and augmented seconds): "Simply to remind that $\mathrm{C}$ major does not have altered notes, and then the seventh degree of a minor is G\#." While they rest with eyes closes, he snaps his fingers setting the tempo and talks quietly. This successfully calms them down despite the occasional (discrete) giggling.

This exercise encouraged them to imagine the sequence of sounds before playing so as to increase performance efficiency. It acted as a stimulus to their cognitive understanding of the scale structure and to their mental imagery abilities or 'inner ear', a skill that musicians consider very important to possess (e.g. Godøy and Jørgensen 2001; Lehmann 1997).

After trying out playing the scales for some more minutes, everyone finally had their break and the second half of the rehearsal session was devoted to rehearsing the concert programme. This means that the maestro did not actually follow through with the threats of delaying the break since, as mentioned earlier, the duration of the two halves of the rehearsal was approximately the same.

\section{The players' (re)actions: cooperation, tiredness, boredom, resistance?}

One should distinguish between the players' default postures in the rehearsal and their reactions to specific actions of conductor and peers. Most of the time, the players' default posture is one of cooperation with conductor and group, through ordered action for and during the achievement of the collective

Boia, Pedro S., and Graça Boal-Palheiros. 2017. Empowering or Boring? Discipline and authority in a Portuguese Sistema-inspired orchestra rehearsal. Action, Criticism, and Theory for Music Education 16 (2): 144-72. doi:10.22176/act16.2.144 
goal of improving performance quality in scale playing (Figure 1-5.1). At times, some of them seem to show signs of tiredness, with their prostrated bodies and heads facing downwards.

The fact that some players picked up their instruments vigorously and got immediately ready to play even after the conductor threatened to postpone the break, suggests they were either enjoying the session and wanted to go on playing, wanted to obey the conductor, or they were making an effort believing it would bring positive outcomes to them, the group and the performance. Occasionally, as previously noted, a player helps the conductor maintain order ("let us hear"; "shush"), which is both a counter-reaction to other participants' disruptive behaviour and an intense collaboration with the conductor in his attempt to discipline participants and manage rehearsal time (subcategory 5.2-two isolated events).

What are the possible meanings of the players' apparent disruptive behaviours? Many giggled, talked, or reacted slowly to the conductors' orders and signals to restart playing, while others seemed motivated and picked up their instruments quickly into playing position and waited for the others (subcategory 5.3). The reasons for the disruptive behaviours might be:

1) Tiredness: it is most likely that inertia and disruptive behaviours were spontaneous and unintentional effects of an accumulation of tiredness due to playing scales for more than one hour after several days of intense rehearsal routine followed by a concert the evening before.

2) Boredom: players might be also bored and demotivated because they felt that scale playing for such a long time was too repetitive and monotonous. Their behaviours might have been a reaction to the contents and dynamics of the session, or a conscious and intentional attempt to express and communicate non-verbally their boredom to the maestro, and their wish to have a different rehearsal. Giggling and talking might have been tension releasing too.

3) Resistance: to what extent was their behaviour a reaction of resistance, an expression of their agency against the conductor's authority and threats? Regardless of their intentions, their inertia and giggling slowed down rehearsal pace and delayed the restart of scale playing. More than merely expressing tiredness or boredom, giggling, keeping unfocused, responding slowly to the maestro's orders, and taking more time to prepare their instruments than he wished, not only allowed

Boia, Pedro S., and Graça Boal-Palheiros. 2017. Empowering or Boring? Discipline and authority in a Portuguese Sistema-inspired orchestra rehearsal. Action, Criticism, and Theory for Music Education 16 (2): 144-72. doi:10.22176/act16.2.144 
them to rest for a few more seconds, but might have been a subtle form of resistance against the conductor's power in defining the type of rehearsal practices and dynamics (e.g. repeating scales).

Were they being slower, noisy and 'unfocused' on purpose? Was that a counter-strategy for slowing down the rehearsal pace? As mentioned previously, a few participants did reveal an overall resistance against the disciplining carried out at OG. It is important to explore the implications of this third possibility.

Against a positive perspective on discipline, Baker's (2014) critical Foucauldian view on El Sistema, grounded on the notions of surveillance, discipline and punishment, highlights negative aspects of discipline and authority (see Foucault 1995). Giddens points out in his structuration theory that Foucault neglects that the least powerful also have agency, seeing them merely as passive individuals subjected to the discipline imposed by the powerful (1984). As Giddens argues, "Foucault's 'bodies' are not agents. Even the most rigorous forms of discipline presume that those subject to them are 'capable' human agents, which is why they have to be 'educated'" $(1984,154)$. Individuals have agency-that is, power to act and eventually influence structuresalthough it is much harder and less likely that they are capable of producing substantial changes.

In this rehearsal, the players had the control upon three resources needed for playing scales and acting according to the maestros' orders: (i) instruments, (ii) their bodies (and learned playing techniques), and to a certain extent (iii) time. Their disruptive reaction relied precisely on their power and ability to control those resources. This reflects the "dialectic of control" which is part of the "two-way character of the distributive aspect of power (power as control)" (Giddens 1984, 374). That is how "the less powerful manage resources in such a way as to exert control over the more powerful in established power relationships" (374). By taking time to start playing, participants were controlling resources and thereby exerting their agency against the maestro, despite his higher status and power. Furthermore, if players' inertia and disruptive behaviour were indeed acts of resistance against the conductor's attempt to discipline and impose upon them what they might have experienced as an intense and repetitive rehearsal dynamics, it is also important to ask if a feeling of being punished perhaps intensified their reactions.

Boia, Pedro S., and Graça Boal-Palheiros. 2017. Empowering or Boring? Discipline and authority in a Portuguese Sistema-inspired orchestra rehearsal. Action, Criticism, and Theory for Music Education 16 (2): 144-72. doi:10.22176/act16.2.144 
"For-all-practical-purposes"-according to their own ethno-methods for making sense of reality (Garfinkel 1967, vii)-some players might have experienced and interpreted the maestro's threat as a positive 'push' that fosters their musical, personal and social development, as suggested in recent research (Lopes, Boia, Veloso, Caldas 2017). However, others might have seen it as an intentional form of punishment for not concentrating and playing the scales well enough. 7 In the latter case, to what extent might their giggling and inertia have been not only an expression of resistance but also of retaliation against the maestro? As previously argued, categorizing the maestro's threat to postpone the break as negative reinforcement or as punishment is a matter of perspective. This ambivalence is impossible to solve from a theoretical point of view. What academics label as 'negative reinforcement' is frequently seen by lay people as 'punishment', which means that common sense does not necessarily make a distinction between the two.

Instead of assuming meanings from a theory, we must follow real people and the meanings they attribute to situations, events, and actions of others. People select 'reasons' from culturally available 'vocabularies of motive' (Mills 1940) to interpret and explain the intentions and actions of others in everyday life situations (e.g. why the maestro threatened to delay the break?). As Atkinson writes, "for the interpretation of everyday practical action, 'motive' is not"-or not only or simply_"a psychological state or predisposition, but rather a culturally available and socially shared frame of reference" (Atkinson 2004, 52). Although people usually have intentions when they act, the interpretation and attribution of those intentions by others is a socially shaped meaning-making process, and is itself an attribution of intentions.

We suggested three possible interpretations of the significance of the participants' (re)actions during the rehearsal session: tiredness, boredom, and resistance, eventually combined in different proportions. To understand them better, it would be necessary to interview the participants and collect their discourses, perceptions, intentions, and explanations about this event. It is nevertheless worth reflecting on these hypotheses, also because of their relevance for the critical discussion that follows.

When they rehearsed the concert repertoire in the second half of the session, everyone seemed satisfied and enjoying playing in a positive atmosphere. This renewed energy supports the interpretation that during the scales of the first half the players were indeed expressing resistance and boredom, besides simply tiredness. At the very end of the rehearsal the conductor gave them

Boia, Pedro S., and Graça Boal-Palheiros. 2017. Empowering or Boring? Discipline and authority in a Portuguese Sistema-inspired orchestra rehearsal. Action, Criticism, and Theory for Music Education 16 (2): 144-72. doi:10.22176/act16.2.144 
positive feedback ("very good!), telling once more he "trusted" them to make a good performance in the concert scheduled to the next day. In the actual concerts the orchestra was disciplined and committed.

\section{Empowering or boring? On the ambivalence of discipline}

Music making can have "transformative power" in artistic-social-educational projects (Tunstall 2012). Whilst orchestral socialization and music learning may indeed reshape participants' dispositions and develop their skills, the transformative capacity attributed to music does not simply emerge from its aesthetic and 'transcendent' 'powers', but rather from conventional, mundane and patterned socio-musical interactions, practices, and discourses.

This case study helps increase our understanding of the actual processes through which change may occur by carrying out empirical observation. As shown, in the specific moment of OG discussed here, such organization of practices comes from a Sistema socio-musical methodological and pedagogical approach embodied in a Venezuelan guest conductor, from OG's local cultural and organizational specificities, as well as by a certain appropriation, by OG and El Sistema, of the 'orchestra' and the 'conductor' as fundamental institutions upon which Western 'classical' music is grounded. It is through this historical, social and cultural framing that music materials and instruments become "active ingredients" of social life and identities (DeNora 2000; 2003), playing a role in the production of social order and turning into constituents of socialization and the internalization of dispositions and skills.

This rehearsal was selected mostly as a case study to discuss discipline, authority, and order in music making and education because these aspects stood out from the video-recorded data, raising questions and stimulating critical reflection on these topics. This provides a privileged opportunity to reflect critically on social order, power, and on the two-edged implications of discipline in these non-formal music education projects.

As Baker (2014) argues, it is necessary to develop a rational rather than an emotional approach to El Sistema, by deconstructing the tendency to idealize it and by revealing its other, less visible, sides. Dispassionate studies and debates are needed regarding if, whether, and how this sort of project produces change. Therefore, it is useful to develop approaches that treat symmetrically both potentially positive and negative aspects, while dealing with their complexity and exploring their contradictions and ambivalence.

Boia, Pedro S., and Graça Boal-Palheiros. 2017. Empowering or Boring? Discipline and authority in a Portuguese Sistema-inspired orchestra rehearsal. Action, Criticism, and Theory for Music Education 16 (2): 144-72. doi:10.22176/act16.2.144 
The role and type of discipline desirable for these projects is one topic that deserves further discussion. Discipline may afford self-regulation, persistence for achieving personal and collective aims, and may be a resource for the pursuit of goals (re)defined by participants themselves including those outside the musical world. As such, discipline may be an important ingredient of the dispositions and skills acquired by participants in OG, since it can act as a resource for their social mobility and empowerment. As advocated by Tunstall (2012) and others, discipline would be a constituent part of the "transformative power of music." However, if too authoritarian, constraining, inflexible or disrespectful of learning styles, social backgrounds, and personality types, it may cause social and psychological harm and, paradoxically, lead to exclusion (see Baker 2014). We need to carry out an empirically grounded reflection on the contradictions and the pros and cons of discipline, exploring its complexity and nuances while avoiding either a priori idealism or over-criticism.

The socio-musical interactions and practices analysed in this article are located and specific and we do not wish to present them as being fully representative of or exclusive to OG. This article focused only on one part of a particular rehearsal with a specific guest conductor at a certain moment of an OG summer camp. While "scale techniques" are used by other OG teachers and conductors as well, this maestro has a certain socio-musical 'personality' and style that is assertive and slightly authoritarian, accompanied by positive expectations and encouraging verbal feedback. Despite common Sistema features observable in different conductors, there was a degree of variation in the styles and pedagogic practices across maestros, even when the level of work intensity and repetition was similar. ${ }^{8}$ Furthermore, at least some of the rehearsal processes examined are not characteristic only of Sistema, and the problems observed are worthy of avoidance no matter the ensemble or socioeducational project.

Our purpose is not to either glorify or detract from the conductor's approach and discipline more generally, but rather to address its complexity and ambivalence. The maestro's final 'lecture' to participants expressed trust in their work and ability, which may be motivating and increase their selfconcept and beliefs about their potential and skill (Hallam 2009). He was demanding and pushed their limits, highlighting the importance of concentration, effort, and persistence in order to play better.

The features of the music itself (many players playing many different parts) and respective aesthetic values and rigorous canon ask for a degree of

Boia, Pedro S., and Graça Boal-Palheiros. 2017. Empowering or Boring? Discipline and authority in a Portuguese Sistema-inspired orchestra rehearsal. Action, Criticism, and Theory for Music Education 16 (2): 144-72. doi:10.22176/act16.2.144 
organized and disciplined practice. However, a degree of authoritarianism of the conductor may be seen as a sort of symbolic violence (Bourdieu and Passeron [1970] 1977) through which middle class and gender values and morality, and a "bourgeois social project," are imposed upon working class children (see Bull 2016). 9 The threat of delaying the break was a form of extrinsic motivation (playing well to get the break), which in turn may be ineffective unless it turns into intrinsic motivation (Sloboda and Davidson 1996).

The love for the music and their instruments emerged as relevant in the experiences of eight out of thirty-five OG young participants studied by Lopes, Boia, Veloso, Caldas $(2017,246-7)$. Those accounts suggest that music and performance as ends in themselves may also have a constructive effect as part of the OG experience by 'drawing out' and developing other dispositions such as self-regulation and responsibility. The music itself matters and fostering "musical passion" and "attachment" (Hennion 2015, Gomart and Hennion 1999) to music and instruments through a rewarding artistic and sensory experience and the emergence of new tastes may be alternative sources of intrinsic motivation that are worth developing in these projects. In his 'lecture', the maestro highlighted the performance as the 'great event' and later on he told them not to play without a purpose but for liking playing and the music, which shows he also sought to explore this kind of intrinsic motivation.

On the other hand, as suggested, 'for all practical purposes', the negative reinforcement events of this rehearsal might have been felt by participants as punishment for not having done well enough. The players' inertia and slow response towards the maestro's approach may also be partially explained by cultural differences between Portugal and Venezuela, related to the perception of what is adequate for children and, eventually, to differences between Portuguese and Venezuelan participants' reactions to a demand of a relatively high level of discipline. ${ }^{10}$ This topic may be related to the tension observed in OG between adopting and adapting a program originally developed in a different country (see Costa, Cruz, and Mota 2017, 121-2).

This rehearsal session raises the question of whether more pleasurable and pedagogically efficient approaches might have been used as an alternative to lengthy repetition of scale playing (see Whitaker 2011, 2017). ${ }^{11}$ About one hour and fifteen minutes of set-up and collective practice of scales can be demotivating and one might ask how much that pedagogy may lead to future dropouts. The over-use of repetition in Sistema (and other) pedagogies, which is likely to be related to the orchestra's ideological underpinnings, calls for

Boia, Pedro S., and Graça Boal-Palheiros. 2017. Empowering or Boring? Discipline and authority in a Portuguese Sistema-inspired orchestra rehearsal. Action, Criticism, and Theory for Music Education 16 (2): 144-72. doi:10.22176/act16.2.144 
continuous re-assessment and redesign of music and orchestra rehearsal pedagogies and practices (see e.g. Whitaker 2011, 2017; Morrison and Demorest 2012).

The mistakes when playing the scales might not have been simply a result of lack of concentration, but a side effect of the El Sistema's pedagogic principle of putting orchestral playing at the centre while devoting a small amount of time to ear training and music theory (see Costa et al. 2017). The participants' scarce knowledge of the relationship between relative keys (majorminor) and scale structure may have created difficulties in playing the scales correctly, especially for those playing transposing instruments. The conductor's verbalized assumption that the wrong notes were due only to tiredness and lack of concentration may have been, in part, a biased attribution of the causes for those difficulties (Heider 1958). If that was the case, continuous repetition was a pedagogically ineffective response. Again, this is a topic for further inquiry.

"Do we have to rehearse again?" was, as Tunstall (2015) recounts from one Sistema US summer camp, the participants' response when their rehearsal break finished. They were enjoying nature and "wanted to hang out by the lake" instead of returning to rehearse. That created a dilemma: "some of the teachers later wondered whether it would have been better to simply let them relax in nature, an experience their urban environments don't often allow." However, conductor Samuel Marchan, "who grew up in El Sistema Venezuela, gently offered a different perspective":

The nature setting was great, and I'm so glad we could give it to them,... but the main thing here is for them to set a high musical goal and find out that through working really hard together, they can achieve something they never knew they could.... It's okay to ask kids to stretch outside of their comfort zones,... as long as we do it with kindness and care. (Tunstall 2015)

"Kids weren't familiar with the new expectations," Tunstall argues. Setting goals and "raising expectations and challenging comfort zones" through collective work may be thus valuable, especially for young students with difficulties to focus and self-regulate, or with less structured trajectories.

The rehearsal session discussed throughout this article was a tour de force of insistence and persistence in which disciplined socio-musical practices played a role in the socialization process. Despite its possible negative aspects, it may have been a 'life lesson' for many of these participants, by fostering a positive attitude towards effort. This refers to dispositions which, being transthority in a Portuguese Sistema-inspired orchestra rehearsal. Action, Criticism, and Theory for Music Education 16 (2): 144-72. doi:10.22176/act16.2.144 
posable to other realms of life (Lahire 2003, [2001] 2011), may increase one's ability to focus and be persistent in the pursuit of one's goals, either musical or extra-musical. On the other hand, as Baker rightly insists, we must think critically on whether musical and educational outcomes and productivity are justifiable at all costs (Baker 2014, 198-200) and if "the end justif[ies] the means" (193).

The historical roots of the orchestra as a strongly hierarchical model of society and the authoritarian profile of the conventional conductor, as well as their link to the capitalist ideals of rationality and productivity, have been subject to criticism (Borchert 2012, Baker 2014). However, we do not have to reify one type of 'orchestra' but can creatively explore other possible incarnations of it. There have been experiences of new, more democratic forms of professional orchestras that may be a source of inspiration.

Similarly, the traditional "from the top" position and role of both the professional and ensemble teaching conductor is something not necessarily static but may be "reframed," as proposed by Morrison and Demorest (2012). The conductor's role may be "expand[ed]" to that of "an expert and professionally trained collaborator" who "works with rather than simply works on younger and less experienced musicians" (840). Identifying problems together, instead of the conductor being the "only" one who does it, facilitates skills transfer. ${ }^{12}$ That means also fostering the "active engagement" of participants instead of limiting their role to simply "following directions," so that "knowledge and skills grow from within" instead of coming all the time "from the top" (Morrison and Demorest 2012). These are important challenges faced today by Sistema, Sistema-inspired and other projects, but also by conservatories and professional music teaching, with implications for the professional music making field as well.

We should neither neglect the importance of pleasure in learning and making music nor undervalue positive forms of discipline. Pushing expectations can develop skills, but it is also important to be flexible and give each participant the vital space to explore, express their experiences, and build their own trajectory, in their own ways.

One specific type of discipline must not be reified as the only possible approach. So-called 'positive discipline', for instance, "says that what children feel and think not only matters, it needs to be acknowledged, addressed and incorporated into the regular structures of the school day for learning to be meaningful" (Nelsen, Lott, and Glenn 2013, x). The aim is to "return to chil-

Boia, Pedro S., and Graça Boal-Palheiros. 2017. Empowering or Boring? Discipline and authority in a Portuguese Sistema-inspired orchestra rehearsal. Action, Criticism, and Theory for Music Education 16 (2): 144-72. doi:10.22176/act16.2.144 
dren a sense of agency and begin to transform their basic relationship with school" "by involving [them] in making decisions about the things that affect them in the classroom, incorporating their suggestions into the class and school agreements, and utilizing their ideas as valuable resources in problem solving, both social and academic" (x).

During the last years, progressive strands in music education, specifically, have made a critique of music education's former ideological underpinnings and conservative practices. This discussion has obvious (even though if not always explicit) consequences for the relationship between discipline, authority and the recognition of learners' agency. O'Neill (2012), for instance, maps recent developments and draws on various contributions to propose a theory of "transformative music engagement" for the music learner of the 21st century. ${ }^{13}$ Learners can and should be empowered through their recognition "as active agents in their own musical development" and by enabling them to autonomously construct their own forms of (citing Green) "music learning authenticity" (O'Neill 2012, 164). According to this view, and despite the previously discussed evidence that points towards social and personal benefits to these players from participating in OG (Lopes, Boia, Veloso, and Caldas 2017), the form of agency expressed by the OG participants during a moment of the rehearsal session analysed here, specifically their resistance to and 'sabotage' of the rehearsal pace (which apparently led the maestro to change strategy), does not reflect the ideal type of learners' agency that should be embraced by educators in accordance with progressive music education.

Both music education and community music must be reflective about the challenges and implications of working with 'at-risk youth' (see Cohen, Silber, Sangiorgio, and Iadeluca 2012). While it is important to not reify the "at-risk youth" label or related stereotypes, it is crucial to avoid symbolic violence and to recognize others as equals, and to avoid reifying one notion of 'inclusion' (and 'exclusion').

The distinction between gentle, positive discipline and authoritarianism, and how the former may be woven into educational practices are relevant issues to reflect on. Similarly, it is important to think of how socio-artistic educators can develop a type of discipline that is emancipatory and respectful rather than just a form of social control aimed at increasing economic productivity, and a way of 'including' that does not merely silence the 'other'. Instead of providing clear-cut answers, we wish to stimulate the debate and encourage further research, reflection, and action.

Boia, Pedro S., and Graça Boal-Palheiros. 2017. Empowering or Boring? Discipline and authority in a Portuguese Sistema-inspired orchestra rehearsal. Action, Criticism, and Theory for Music Education 16 (2): 144-72. doi:10.22176/act16.2.144 
This article does not follow any sort of narrowed 'middle-way' or 'asepticized' perspective which, devoid of critical thinking, strives to remain evenhanded and neutral at all cost by narrowing its focus to just 'more or less positive or negative' or 'we cannot really tell' aspects of Sistema(-inspired) programs. While it remains necessary to approach 'in-between' nuances in order to carry out an in-depth exploration of complexity, we advocate covering the entire spectrum between aspects that might be seen as representing both the potentially positive and negative extremes.

In short, through the case study and the discussion presented here we intend to propose a perspective equally open to both positive and negative sides of El Sistema and comparable projects and without narrowing its scope to any of those dimensions. This is crucial for developing a rational and analytical approach to El Sistema, so much in need as pointed out by Baker (2014). To effectively accomplish such a project one must prevent academic research from falling into the trap of allowing itself to tacitly become a counterdiscourse opposed to the publicized dominant view, by focusing mostly or exclusively on the program's negative sides, as scholarship would remain incomplete and biased. By demonstrating how a symmetrical view may help highlight and further explore complexity, contradiction, and ambivalence, it is also our aim to contribute to and push the current debate on Sistema(inspired) programs beyond the apparent tendency of polarization of positions between proponents and detractors.

\begin{abstract}
About the Authors
Pedro S. Boia is an FCT Postdoctoral Fellow at CIPEM - Centro de Investigação em Psicologia da Música e Educação Musical at Porto Polytechnic, which is part of INET-md - Instituto de Etnomusicologia - Centro de Estudos em Música e Dança, and researcher at Instituto de Sociologia of the University of Porto (Portugal). He holds a PhD in Sociology from the University of Exeter (UK), a Master's from the University of Coimbra (MA) and a Bachelor's degree from the University of Porto, both in Sociology. He studied Music at the Porto Music Conservatoire and the Royal Conservatoire of The Hague (The Netherlands), and was a Visiting Scholar at the Faculty of Music of the University of Cambridge and at the CMPCP - Research Centre for Music Performance as Creative Practice. Boia has done research on Orquestra Geração (El Sistemainspired program), viola performance and aesthetics, and clubbing and gender identities. He is managing editor of the peer-reviewed journal Music \& Arts in Action (SocArts, University of Exeter).
\end{abstract}

Boia, Pedro S., and Graça Boal-Palheiros. 2017. Empowering or Boring? Discipline and authority in a Portuguese Sistema-inspired orchestra rehearsal. Action, Criticism, and Theory for Music Education 16 (2): 144-72. doi:10.22176/act16.2.144 
Graça Boal-Palheiros is Adjunct-Professor and coordinates the Master in $\mathrm{Mu}-$ sic Education at the School of Education of Porto Polytechnic, Portugal. She received a PhD in Music Psychology (University of Surrey, London), an MA in Music Education (University of London Institute of Education), a BA in Music Pedagogy (University of Leuven Lemmens Institute, Belgium) and a degree in Psychology (University of Porto, Portugal). Graça has been a member of the International Society for Music Education Board and Executive, chair of its INA Committee and co-chair of the ISME Research Commission. Former president of the APEM - Portuguese Association of Music Education and editor of the APEM Journal. Co-founder and president of the Wuytack Association of Music Pedagogy, she coordinates its Teacher Education Centre as well as editorial and musical projects. She is a researcher at CIPEM/ INET-md. Her interests include children's music listening and singing, music teacher education and social inclusion.

\section{References}

Atkinson, Paul. 2004. Performance, culture and the sociology of education. International Studies in Sociology of Education 14 (2): 147-65.

Austin, John. 1962. How to do things with words. The William James lectures delivered at Harvard University in 1955. Oxford: Clarendon.

Baker, Geoffrey. 2014. El Sistema: Orchestrating Venezuela's youth. Oxford: Oxford University Press.

Baker, Geoffrey. 2016. Editorial introduction: El Sistema in critical perspective Action, Criticism \& Theory for Music Education 15 (1), Special Issue: El Sistema. http://act.maydaygroup.org/articles/Baker15_1.pdf

Bates, Vincent C. 2016. Foreword: how can music educators address poverty and inequality? Action, Criticism \& Theory for Music Education 15 (1), Special Issue: El Sistema. http://act.maydaygroup.org/articles/Bates15_1.pdf

Borchert, Gustavo. 2012. El Sistema: A subjectivity of time discipline. In Os tempos sociais e o mundo contemporâneo: um debate para as ciências sociais e humanas, eds. Emília Araújo and Eduardo Duque, 59-79. Braga: CECS /CICS, Universidade do Minho.

Bourdieu, Pierre. (1972) 1977. Outline of a theory of practice. Cambridge: Cambridge University Press.

Boia, Pedro S., and Graça Boal-Palheiros. 2017. Empowering or Boring? Discipline and authority in a Portuguese Sistema-inspired orchestra rehearsal. Action, Criticism, and Theory for Music Education 16 (2): 144-72. doi:10.22176/act16.2.144 
Bourdieu, Pierre. (1980) 1990. The logic of practice. Cambridge: Polity Press.

Bourdieu, Pierre, and Jean-Claude Passeron. (1970) 1977. Reproduction in education, society, and culture. London: Sage.

Bull, Anna. 2016. El Sistema as a bourgeois social project: class, gender, and Victorian values. Action, Criticism \& Theory for Music Education 15 (1), Special Issue: $\quad \mathrm{El}$ Sistema. http://act.maydaygroup.org/articles/Bull15_1.pdf

Cohen, Mary L., Laya H. Silber, Andrea Sangiorgio, and Valentina Iadeluca. 2012. At-risk youth: Music-making as a means to promote positive relationships. In The Oxford handbook of Music Education, vol. 2, eds. Gary E. McPherson and Graham F. Welch, 185-202. Oxford: Oxford University Press.

Costa, Jorge A., Ana Cruz, Rui Ferreira, Rui Bessa, Graça Boal-Palheiros, and Pedro S. Boia. 2017. Aprender música na Orquestra Geração. In Crescer a tocar na Orquestra Geração, eds. Graça Mota and João T. Lopes, 127-57. Vila do Conde: O Verso da História.

Costa, Jorge A., Ana Cruz, and Graça Mota. 2017. O desvendar de uma complexidade. In Crescer a tocar na Orquestra Geração, eds. Graça Mota and João T. Lopes, 111-26. Vila do Conde: O Verso da História.

Creech, Andrea, Patricia González-Moreno, Lisa Lorenzino, and Grace Waitman. 2016. El Sistema and Sistema-inspired programmes: A literature review of research, evaluation, and critical debates. San Diego: Sistema Global.

DeNora, Tia. 2000. Music in everyday life. Cambridge: Cambridge University Press.

DeNora, Tia. 2003. After Adorno: Rethinking music sociology. Cambridge: Cambridge University Press.

Dineen, Phillip M. 2011. Gestural economies in conducting. In New perspective on music and gesture, eds. Anthony Gritten and Elaine King, 131-57. Farnham: Ashgate.

Boia, Pedro S., and Graça Boal-Palheiros. 2017. Empowering or Boring? Discipline and authority in a Portuguese Sistema-inspired orchestra rehearsal. Action, Criticism, and Theory for Music Education 16 (2): 144-72. doi:10.22176/act16.2.144 
Foucault, Michel. 1995. Discipline \& punish: The birth of the prison. Second edition. New York: Vintage Books.

Garfinkel, Harold. 1967. Studies in ethnomethodology. Englewood Cliffs: Prentice-Hall.

Giddens, Anthony. 1984. The constitution of society: Outline of the theory of structuration. Cambridge, UK: Polity Press.

Godøy, Rolf I. and Harald Jørgensen. 2001. Musical imagery. Lisse: Swets \& Zeitlinger.

Godøy, Rolf I. 2010. Gestural affordances of musical sound. In Musical gestures: sound, movement, and meaning, eds. Rolf I. Godøy and Marc Leman, 103-25. New York: Routledge.

Gomart, Emilie, and Antoine Hennion. 1999. A sociology of attachment: music amateurs, drug users. In Actor-Network Theory and After, eds. John Law and John Hassard, 220-247. Oxford: Blackwell.

Hallam, Susan. 2009. Motivation to learn. In The Oxford handbook of music psychology, edited by Susan Hallam, Ian Cross and Michael Thaut, 28594. Oxford: Oxford University Press.

Heath, Christian, Jon Hindmarsh, and Paul Luff. 2010. Video in qualitative research: Analysing social interaction in everyday life. London: Sage.

Heider, Fritz. 1958. The Psychology of interpersonal relations. New York: Wiley.

Hennion, Antoine. 2015. The Passion for music: A Sociology of mediation. Farnham: Ashgate.

Knussen, Sue, dir. 1994. The art of conducting: great conductors of the past. [Video-documentary]. Hamburg: Teldec.

Koivunen, Niina. 2011. Show us the sound! Aesthetic leadership of symphony orchestra conductors. Leadership 7 (1): 51-71.

Boia, Pedro S., and Graça Boal-Palheiros. 2017. Empowering or Boring? Discipline and authority in a Portuguese Sistema-inspired orchestra rehearsal. Action, Criticism, and Theory for Music Education 16 (2): 144-72. doi:10.22176/act16.2.144 
Lahire, Bernard. 2003. From the habitus to an individual heritage of dispositions: towards a sociology at the level of the individual. Poetics $31(5-6)$ : 329-55.

Lahire, Bernard. (2001) 2011. The plural actor. Cambridge: Polity Press.

Lehmann, Andreas C. 1997. Acquired mental representations in musical performance: anedoctal and preliminary empirical evidence. In Does practice make perfect? Current theory and research on instrumental music practice, eds. Harald Jørgensen and Andreas C. Lehmann, 141-63. Oslo: $\mathrm{NMH}$.

Lopes, João T., Pedro S. Boia, Ana Veloso, and Matilde Caldas. 2017. Retratos sociológicos: socialização de orquestra, percursos, vivências. In Crescer a tocar na Orquestra Geração, eds. Graça Mota and João T. Lopes, 173250. Vila do Conde: O Verso da História.

Mauss, Marcel. (1934) 1973. Techniques of the body. Economy and Society 2 (1): $70-88$.

Mills, Charles W. 1940. Situated actions and vocabularies of motive. American Sociological Review 5: 904-13.

Morrison, Steven J., and Steven M. Demorest. 2012. Once from the top: reframing the role of the conductor in ensemble teaching. In The Oxford handbook of Music Education, vol. 1, eds. Gary E. McPherson and Graham F. Welch, 826-43. Oxford: Oxford University Press.

Mota, Graça, and João T. Lopes, eds. 2017. Crescer a tocar na Orquestra Geração. Vila do Conde: O Verso da História.

Nelson, Jane, Lynn Lott, and H. Stephen Glenn. 2013. Positive discipline in the classroom: Developing mutual respect, cooperation, and responsibility in your classroom. Fourth edition. New York: Three Rivers Press.

O'Neill, Susan. 2012. Becoming a music learner: toward a theory of transformative music engagement. In The Oxford handbook of Music Education, vol. 1, eds. Gary E. McPherson and Graham F. Welch, 163-86. Oxford: Oxford University Press.

Boia, Pedro S., and Graça Boal-Palheiros. 2017. Empowering or Boring? Discipline and authority in a Portuguese Sistema-inspired orchestra rehearsal. Action, Criticism, and Theory for Music Education 16 (2): 144-72. doi:10.22176/act16.2.144 
Schutz, Alfred. 1951. Making music together: A study in social relationship. Social Research 18 (1): 76-97.

Searle, John R. 1969. Speech acts: an essay in the philosophy of language. Cambridge: Cambridge University Press.

Skinner, Burrhus F. (1953) 2014). Science and human behavior. The B. F. Skinner Foundation. http://bfskinner.org/store/

Sloboda, John, and Jane Davidson. 1996. The young performing musician. In Musical beginnings: The origins and development of musical competence, eds. Irène Deliège and John Sloboda, 171-90. London: Oxford University Press.

Spitzer, J., and Neil Zaslaw. n.d.. Orchestra. Grove Music Online - Oxford Music Online. Oxford University Press. http://www.oxfordmusiconline.com/subscriber/article/grove/music/204 02

Spitzer, J., N. Zaslaw, and M. Kennedy. n.d. The conductor. The New Grove Dictionary of Opera (Ed. Stanley Sadie). Grove Music Online - Oxford Music Online. Oxford University Press. http://www.oxfordmusiconline.com/subscriber/article/grove/music/O9o 1114

Stake, Robert. 2008. Qualitative case studies. In Strategies of qualitative inquiry, eds. Norman K. Denzin and Yvonna S. Lincoln, 119-49. Los Angeles: Sage.

Tunstall, Tricia. 2012. Changing lives: Gustavo Dudamel, El Sistema, and the transformative power of music. New York: Norton.

Tunstall, Tricia. 2015. "Do we have to rehearse again?" The Ensemble - A Newsletter for the U.S. \& Canadian El Sistema Movement, September 2015. http://ericbooth.net/the-ensemble/

Verhagen, Franka, Leonardo Panigada, Ronnie Morales. 2016. El Sistema Nacional de Orquestas y coros juveniles e infantiles de Venezuela: un modelo pedagógico de inclusión social a través de la excelência musical. Revista Internacional de Educación Musical 4: 35-45. http://revistaeducacionmusical.org/index.php/rem1/article/view/90 
Whitaker, Jennifer A. 2011. High school band students' and directors' perceptions of verbal and nonverbal teaching behaviors. Journal of Research in Music Education 59 (3): 290-309.

Whitaker, Jennifer A. 2017. Professional orchestral conductors' use of selected teaching behaviors in rehearsal. International Journal of Music Education 35 (2): 165-74.

\section{Notes}

${ }^{1}$ This article is based on a follow-up of a previous research project carried out by CIPEM/INET-md and Instituto de Sociologia of Porto University, supported by FCT - Fundação para a Ciência e a Tecnologia/ Portuguese Ministry of Science and funded by FEDER Competitiveness Operational Programme COMPETE and National Funds (PTDC/CPE-CED/120596/2010).

${ }^{2}$ These sociological portraits included participants in the orchestra rehearsal session analyzed in this article.

3 This is an explicit concern of the project implementers and leaders, even if, due to local specificities of the project, it has been pointed out that such "intensity" in OG is considerably lower than in Venezuela's El Sistema.

4 The nuclei under study had been filmed in earlier occasions. Some of these participants were also video-recorded during their instrument lessons.

5 OG orchestral ensembles were, at the time, divided into four levels (A, B, C, $D$ ) in which ' $A$ ' orchestras were composed of the older and most musically most advanced players and 'D' orchestras were formed by younger beginners.

${ }^{6}$ One of the times, the conductor speaks specifically to a flute player, probably also as a way to improve her breathing and embouchure by making her seat straight.

7 In negative reinforcement, the stimulus may be as physically or psychologically aversive as in punishment, and may be used to achieve 'immediate mode of control'. As Skinner writes: 'One boy holds another on the ground until the victim cries "Uncle." (...) A horse is whipped until it moves at a given speed. We use conditioned aversive stimuli in the same way-when, for example, we "shame" someone into acting.' (op cit.: 174). Even assuming the maestro's intention was not to punish, we do not know if participants interpreted it that way nor how successful his final 'lecture' was in framing their interpretation of the 'threat' as a positive encouragement rather than a sanction.

Boia, Pedro S., and Graça Boal-Palheiros. 2017. Empowering or Boring? Discipline and authority in a Portuguese Sistema-inspired orchestra rehearsal. Action, Criticism, and Theory for Music Education 16 (2): 144-72. doi:10.22176/act16.2.144 
8 Observation has shown that other guest or resident OG conductors from Venezuela with a Sistema background and training were somewhat 'softer' and less authoritarian with players.

9 Symbolic violence, of course, may have social class but also ethnic implications.

${ }^{10}$ During an interview, former OG national coordinators (who had been part of Venezuela's El Sistema) expressed the view that in the Portuguese OG there is an exaggerated concern with issues such as the length and work intensity of summer camp rehearsals, the well-being of children, how frequently they have lunch breaks, etc. They see that as a handicap that prevents the project from achieving the necessary level of "intensity" and the desirable socio-musical outcomes. The ethical responsibility of acknowledging children's rights and well-being emerges as a relevant issue for every music educator, but although the topic would deserve further discussion it is very complex and cannot be addressed here. The discussion would nevertheless have to consider questions of cultural relativism versus ethnocentrism (either from a South-American or European perspective) and, if one stands for certain human and educational values, what range of cultural variation might be admissible in the definition of the criteria and practical materialization of children's well-being. It would imply carrying out a comparative study and collecting empirical data on the organization, scheduling and logistics of the two programs, as well as studying the representations, discourses and values of their protagonists observing how their actual practical materialization takes place.

${ }^{11}$ Whitaker's studies also discuss relevant literature on rehearsal methodology and practices by conductors teaching at different levels and professional conductors, relevant to the issue of rehearsal efficiency.

12 During the conductor's verbal feedback (above), he stimulated young players' own self-assessment ("lack of concentration"), thus identifying a problem together with them.

${ }_{13}$ Obviously, the literature is too vast and the relevant contributions too many to be discussed within the scope of this article. 